\section{Evaluation of 'Miniverde' Bermudagrass and 'Diamond' Zoysiagrass Putting Green Establishment using Granular Fertilizer Applications}

\author{
Kyle Briscoe \\ Department of Plant and Soil Sciences, Mississippi State University, 117 Dorman \\ Hall, Mississippi State, MS 39762
}

\author{
Grady Miller ${ }^{1}$, Scott Brinton, Dan Bowman, and Charles Peacock \\ Crop Science Department, North Carolina State University, 100 Derieux Place, \\ Raleigh, NC 27695-7620
}

Additional index words. Cynodon dactylon $\times$ C. transvaalensis, Zoysia matrella, sprigs, golf course, transition zone

\begin{abstract}
Miniverde' bermudagrass [Cynodon dactylon (L.) Pers. $\times$ C. transvaalensis (Burtt-Davy)] and 'Diamond' zoysiagrass [Zoysia matrella (L.) Merr.] are becoming more widely used on putting greens in the transition zone. Field studies were conducted from June through Aug. 2008 and 2009 in Raleigh, NC, and in Jackson Springs, NC, respectively. The objective was to determine the influence of granular fertilizer programs consisting of various nitrogen $(N)$ sources and rates on the establishment of 'Miniverde' and 'Diamond' from sprigs. In 2008, the experimental area consisted of a putting green built to U.S. Golf Association (USGA) recommendations [85 sand:15 peat (v/v)]. A native sandy-soil putting green was used in 2009. Fertilizer programs consisting of stabilized urea, polymer-coated urea, and a combination of stabilized urea and activated sewage sludge were initiated 1 week after planting (WAP). Nitrogen rates ranged from 12 to $48 \mathrm{~kg} \cdot \mathrm{ha}^{-1}$ / week. Nitrogen source and rate differentially influenced turf color and establishment. The combination program increased color of both grasses to an acceptable level earlier than other programs. Coverage rates of both grasses under the combination program were significantly higher than other programs across both years. Despite having the most total $N$ applied, the polymer-coated urea program did not significantly enhance bermudagrass and zoysiagrass color or establishment compared with other programs. Increasing the $\mathbf{N}$ rate of stabilized urea from 12 to $24 \mathrm{~kg} \cdot \mathrm{ha}^{-1} /$ week did not increase establishment for either grass. This research indicates that 'Miniverde' bermudagrass and 'Diamond' zoysiagrass planted in the summer can be completely established from sprigs in the transition zone using granular fertilizer. However, turfgrass color and coverage may vary depending on $\mathbf{N}$ sources and rates within the fertilizer program.
\end{abstract}

Providing adequate fertility during turf establishment from sprigs on sand-based putting greens is necessary because the soil is typically nutrient-deficient (Rodriguez et al., 2001). Furthermore, differences in fertility requirements between grass species may influence the rate and source of nutrients that are applied. Recently, ultradwarf bermudagrasses [Cynodon dactylon (L.) Pers. $\times$ C. transvaalensis (Burtt-Davy)] have become more widely used on golf course putting greens in the southeastern United States. The ultradwarfs have finer leaf texture and higher shoot density compared with dwarf bermudagrasses (McCarty and Miller, 2002).

Received for publication 9 Apr. 2012. Accepted for publication 10 May 2012.

We thank New Life Turf for the donation of 'Diamond' zoysiagrass sprigs and Modern Turf for the donation of 'Miniverde' bermudagrass sprigs.

${ }^{1}$ To whom reprint requests should be addressed; e-mail Grady_miller@ncsu.edu. during establishment. Their results suggest increasing $\mathrm{N}$ rates applied weekly may be necessary for rapid establishment of the ultradwarfs from sprigs.

Poor shade tolerance can limit ultradwarf use on shaded putting greens (Bunnell et al., 2005). The use of 'Diamond' [Zoysia matrella (L.) Merr.], a fine textured zoysiagrass, has been evaluated for shaded putting greens. 'Diamond' has superior shade tolerance compared with bermudagrass (Engelke et al., 2002). However, zoysiagrass has been shown to establish more slowly than bermudagrass (Busey and Myers, 1979; Patton et al., 2004). Busey and Myers (1979) found that the coverage rate of 'Tifgreen' bermudagrass [Cynodon dactylon (L.) Pers. $\times$ C. transvaalensis $]$ was greater than that of Japanese zoysiagrass (Zoysia japonica Steud.). Furthermore, 'Mirage' bermudagrass [Cynodon dactylon var. dactylon (L.) Pers.] reached $100 \%$ coverage $24 \mathrm{~d}$ earlier than 'Zenith' zoysiagrass (Zoysia japonica Steud.) (Patton et al., 2004). The slow establishment rate is perceived to be a major limitation to the use of zoysiagrass as a putting green turfgrass.

Similar to bermudagrass, increasing $\mathrm{N}$ rates and application frequencies have been used with limited success to maximize zoysiagrass establishment from sprigs. Carroll et al. (1997) found that applying $\mathrm{N}$ at $48 \mathrm{~kg} \cdot \mathrm{ha}^{-1} /$ month to 'Meyer' zoysiagrass (Zoysia japonica Steud.) only increased coverage up to $5 \%$ compared with sprigs receiving only $\mathrm{N}$ at planting. These results agree with those of Richardson and Boyd (2001), who concluded $\mathrm{N}$ rates of 13 to $50 \mathrm{~kg} \cdot \mathrm{ha}^{-1} / \mathrm{month}$ had little to no effect on the establishment of 'Meyer'. Furthermore, Stiglbauer et al. (2009) found that neither N source nor rate influenced the establishment rate of 'Diamond' zoysiagrass from sprigs.

Fertilizer programs consisting of various $\mathrm{N}$ sources and rates are often recommended for the establishment of putting greens. This requires turfgrass managers to make weekly fertilization decisions during the establishment period. Furthermore, information on granular fertilizer programs for the establishment of ultradwarf bermudagrass and fine-textured zoysiagrass is limited. Therefore, the objective of the study was to evaluate the influence of $\mathrm{N}$ source and rate on 'Miniverde' bermudagrass and 'Diamond' zoysiagrass establishment in the transition zone.

\section{Materials and Methods}

This study was established in June 2008 and June 2009. The 2008 trial was conducted at the Lake Wheeler Field Laboratory located in Raleigh, NC. The experimental area was constructed as a golf course putting green using an 85 sand:15 peat $(\mathrm{v} / \mathrm{v})$ root zone to meet USGA recommendations (USGA Green Section Staff, 1993). The soil had a $\mathrm{pH}$ of 5.5 and a phosphorus $(\mathrm{P})$ and potassium (K) content of $14 \mathrm{~kg} \cdot \mathrm{ha}^{-1}$ and $35 \mathrm{~kg} \cdot \mathrm{ha}^{-1}$, respectively. The 2009 trial was conducted on a native soil at the Sandhills Research Station located in Jackson Springs, NC. The soil was a Candor sand (Sandy, kaolinitic, 
thermic Grossarenic Kandiudults) (USDANRCS Soil Survey Division, 2008) with a $\mathrm{pH}$ of $5.8,59 \mathrm{~kg} \cdot \mathrm{ha}^{-1} \mathrm{P}$, and $25 \mathrm{~kg} \cdot \mathrm{ha}^{-1} \mathrm{~K}$.

'Diamond' zoysiagrass [Zoysia matrella (L.) Merr.] sprigs provided by New Life Turf (Norway, SC) were planted on 29 May 2008 and 2 June 2009 at a rate of $133 \mathrm{~m}^{3} \cdot \mathrm{ha}^{-1}$ (35 bushels $/ 1000 \mathrm{ft}^{2}$ ). 'Miniverde' bermudagrass sprigs provided by Modern Turf (Rembert, SC) were planted on 30 May 2008 and 28 May 2009 a rate of $76 \mathrm{~m}^{3} \cdot \mathrm{ha}^{-1}$ (20 bushels/ $1000 \mathrm{ft}^{2}$ ). 'Diamond' was sprigged at a higher rate than 'Miniverde' because zoysiagrass has been shown to have a slower establishment rate than bermudagrass. To increase sprig to soil contact, a tractor-mounted cultipacker was used to punch the sprigs into the soil.

Five granular fertilizer programs were initiated 5 June 2008 and 9 June 2009 (Table 1). Three programs consisted of stabilized urea (Uflexx; Agrotain Intl., St. Louis, MO) applied at an $\mathrm{N}$ rate of 12 to $24 \mathrm{~kg} \cdot \mathrm{ha}^{-1} /$ week, the fourth program consisted of polymer-coated urea applied at an $\mathrm{N}$ rate of $96 \mathrm{~kg} \cdot \mathrm{ha}^{-1} / \mathrm{month}$, and the fifth was stabilized urea applied at an $\mathrm{N}$ rate of $12 \mathrm{~kg} \cdot \mathrm{ha}^{-1} /$ week coupled with activated sewage sludge at an $\mathrm{N}$ rate of $48 \mathrm{~kg} \cdot \mathrm{ha}^{-1}$ every 3 weeks. Uflexx contains N-(nbutyl) thiophosphoric triamide (urease inhibitor) and dicyandiamide (a nitrification inhibitor), which act to slow the rate of urea hydrolysis and slow the conversion of ammonium to nitrate, respectively. Uflexx was used for these programs to minimize leaching and denitrification because the turf was established during the warmer months and under irrigated conditions to keep moisture level high.

Weekly N accumulation of the five programs is detailed in Table 2. Both studies were arranged in a randomized complete block with four replications on each grass. Weekly fertilizer applications were made for 12 consecutive weeks using shaker bottles. In addition to the scheduled $\mathrm{N}$ fertilizer, $\mathrm{P}$ was applied as triple superphosphate (0N-20.1P$0 \mathrm{~K}$ ) at a rate of $11 \mathrm{~kg} \cdot \mathrm{ha}^{-1}$ and $\mathrm{K}$ as potassium chloride $(0 \mathrm{~N}-0 \mathrm{P}-51.5 \mathrm{~K})$ at a rate of $40 \mathrm{~kg} \cdot \mathrm{ha}^{-1}$ 1,5 , and 9 WAP using a rotary spreader.

Irrigation was applied as needed to maintain high soil moisture (avoid stress) throughout the establishment periods. Mowing was initiated on 21 July 2008 and 22 July 2009 at a height of $12.7 \mathrm{~mm}$ using a walk-behind reel mower. Starting 28 July 2008 and 4 Aug. 2009, plots were mowed at $6.4 \mathrm{~mm}$ three times per week for the remainder of the study. Typical putting green mowing heights $(\approx 3.2 \mathrm{~mm})$ were never implemented as a result of low zoysiagrass coverage and to avoid scalping the bermudagrass.

Daily maximum and minimum temperatures were collected for both locations during the establishment periods (Fig. 1). Visual turfgrass color and coverage ratings were collected weekly from 5 to 13 WAP. Color and coverage were evaluated following the National Turfgrass Evaluation guidelines (Morris and Shearman, 2008). Turfgrass color was measured on a 1 to 9 scale in which $1=$ brown turf, $6=$ acceptable green color, $9=$ dark green color. Visual turfgrass coverage was measured on a

Table 1. Fertilizer program name, fertilizer(s) used, N rates, N-P-K ratios, and application weeks used for the establishment of 'Miniverde' bermudagrass and 'Diamond' zoysiagrass June through Aug. 2008 in Raleigh, NC, and June through Aug. 2009 in Jackson Springs, NC. ${ }^{z}$

\begin{tabular}{|c|c|c|c|c|}
\hline Program name & Fertilizer $^{y}$ & $\mathrm{~N}$ rate $\left(\mathrm{kg} \cdot \mathrm{ha}^{-1}\right)$ & $\mathrm{N}-\mathrm{P}-\mathrm{K}$ ratio & App. wk (WAP) \\
\hline$\overline{\mathrm{SU}}-1.2$ & $\begin{array}{l}\text { Stabilized urea } \\
\quad(46 \mathrm{~N}-0 \mathrm{P}-0 \mathrm{~K})\end{array}$ & 12 & $4.4: 1: 3.6$ & $1-12$ \\
\hline $\mathrm{SU}-2.4$ & Stabilized urea & 24 & $8.8: 1: 3.6$ & $1-12$ \\
\hline \multirow[t]{3}{*}{ SU Progressive } & Stabilized urea & 12 & $6.6: 1: 3.6$ & $1-4$ \\
\hline & Stabilized urea & 18 & & $5-8$ \\
\hline & Stabilized urea & 24 & & $9-12$ \\
\hline PCU & $\begin{array}{l}\text { Polymer-coated urea } \\
(43 \mathrm{~N}-0 \mathrm{P}-0 \mathrm{~K})\end{array}$ & 96 & $11.6: 1: 3.6$ & $1,5,9,12$ \\
\hline \multirow[t]{2}{*}{$\mathrm{SU}-1.2+\mathrm{O}$} & Stabilized urea & 12 & $5.6: 1: 2$ & $1-12$ \\
\hline & $\begin{array}{l}\text { Activated } \\
\text { sewage sludge } \\
(6 \mathrm{~N}-0.9 \mathrm{P}-0 \mathrm{~K})\end{array}$ & 48 & & $1,4,7,10$ \\
\hline
\end{tabular}

zThe five granular fertilizer programs were initiated 5 June 2008 and 9 June 2009.

y In addition to the scheduled fertilizer that was applied each week, $\mathrm{P}$ was applied as triple superphosphate $(0 \mathrm{~N}-20.1 \mathrm{P}-0 \mathrm{~K})$ at a rate of $11 \mathrm{~kg} \cdot \mathrm{ha}^{-1}$ and $\mathrm{K}$ as potassium chloride $(0 \mathrm{~N}-0 \mathrm{P}-51.5 \mathrm{~K})$ at a rate of $40 \mathrm{~kg} \cdot \mathrm{ha}^{-1}$ 1,5 , and 9 weeks after planting (WAP).

$\mathrm{N}=$ nitrogen; $\mathrm{P}=$ phosphorus; $\mathrm{K}$ = potassium; $\mathrm{PCU}=$ polymer-coated urea.

Table 2. Weekly $\mathrm{N}$ accumulation of five granular fertilizer programs applied to 'Miniverde' bermudagrass and 'Diamond' zoysiagrass during the 2008 and 2009 establishment periods.

\begin{tabular}{|c|c|c|c|c|c|c|c|c|c|c|c|c|}
\hline \multirow[b]{3}{*}{ Program name } & \multicolumn{12}{|c|}{ Weeks after planting } \\
\hline & 1 & 2 & 3 & 4 & 5 & 6 & 7 & 8 & 9 & 10 & 11 & 12 \\
\hline & \multicolumn{12}{|c|}{$\mathrm{N}$ accumulation $\left(\mathrm{kg} \cdot \mathrm{ha}^{-1}\right)$} \\
\hline $\mathrm{SU}^{\mathrm{z}}-1.2$ & 12 & 24 & 36 & 48 & 60 & 72 & 84 & 96 & 108 & 120 & 132 & $\overline{144}$ \\
\hline $\mathrm{SU}-2.4$ & 24 & 48 & 72 & 96 & 120 & 144 & 168 & 192 & 216 & 240 & 264 & 288 \\
\hline SU Progressive & 12 & 24 & 36 & 48 & 66 & 84 & 102 & 120 & 144 & 168 & 192 & 216 \\
\hline $\mathrm{PCU}^{\mathrm{y}}$ & 96 & 96 & 96 & 96 & 192 & 192 & 192 & 192 & 288 & 288 & 288 & 384 \\
\hline $\mathrm{SU}-1.2+\mathrm{O}^{\mathrm{x}}$ & 60 & 72 & 84 & 144 & 156 & 168 & 180 & 240 & 252 & 264 & 324 & 336 \\
\hline
\end{tabular}

${ }^{\mathrm{z}} \mathrm{SU}=$ stabilized urea.

yCU = poly-coated urea.

${ }^{\mathrm{x}} \mathrm{O}=$ organic (activated sewage sludge).

$\mathrm{N}=$ nitrogen.

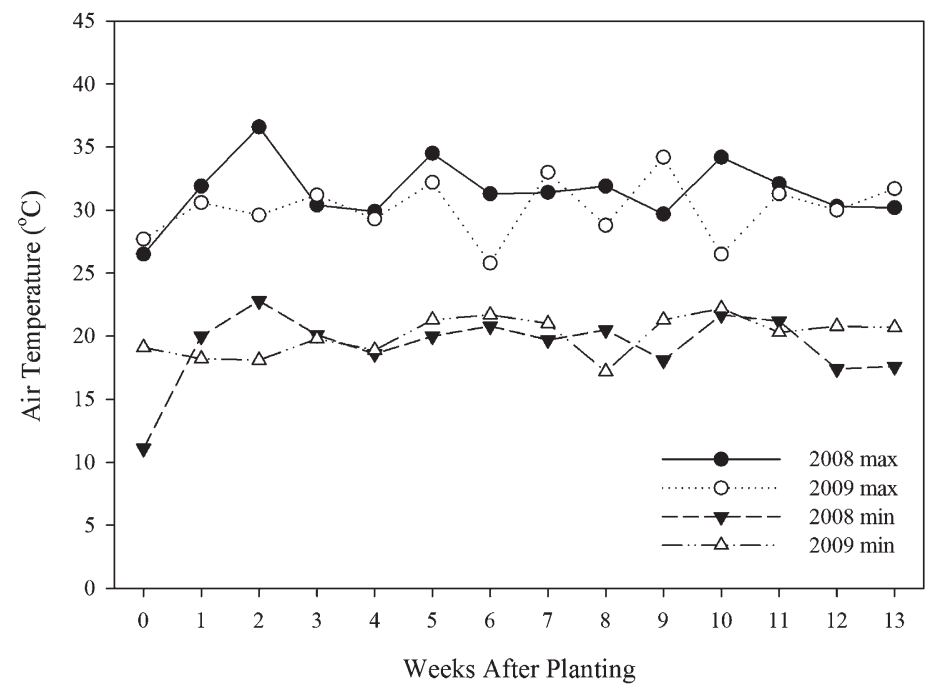

Fig. 1. Daily maximum and minimum air temperatures $\left({ }^{\circ} \mathrm{C}\right)$ recorded 25 May to 30 Aug. 2008 at Lake Wheeler Field Laboratory in Raleigh, NC, and 25 May to 30 Aug. 2009 at Sandhills Research Station in Jackson Springs, NC.

0 to $100 \%$ scale $(0 \%=$ no cover and $100 \%=$ full coverage).

Weekly photographs were taken directly overhead each plot with a digital camera attached to a $46-\mathrm{cm}$ horizontal arm mounted $90^{\circ}$ to the vertical axis of a $91-\mathrm{cm}$ tripod. The images were batch analyzed using a turf analysis macro (Karcher and Richardson, 2005) for SigmaScan Pro software (Version 5.0; SPSS
Science Marketing Dep., Chicago, IL) to determine percent green pixels in each photo. A weighted-mean coverage rate was calculated by dividing percent coverage by days after planting.

All statistical analyses were performed using Statistical Analysis System (Version 9.1; SAS Inst., Cary, NC). The main and interaction effects were examined with analysis 
of variance. Fisher's least significant difference test was used to separate treatment means. The data from each grass were separated by year resulting from an interaction between fertilizer program and year (Table 3). Furthermore, the data were separated by WAP as a result of an interaction between week and fertilizer program.

\section{Results and Discussion}

Turfgrass color. The program that incorporated a combination of stabilized urea and organic fertilizer $(\mathrm{SU}-1.2+\mathrm{O})$ followed by the $\mathrm{SU}-2.4(24 \mathrm{~kg} \mathrm{~N} / \mathrm{ha} /$ week) fertilizer programs generally provided the greatest increase in bermudagrass and zoysiagrass color over the establishment period (Fig. 2). The $\mathrm{SU}-1.2+\mathrm{O}$ consistently provided acceptable bermudagrass and zoysiagrass color 7 to 13 WAP. Guertal and Evans (2006) found that turf color of the ultradwarf bermudagrass 'Tifeagle' was maximized at $\mathrm{N}$ rates from 33 to $48 \mathrm{~kg} \cdot \mathrm{ha}^{-1} /$ week. These rates were higher than this study. However, SU -2.4 did provide acceptable bermudagrass and zoysiagrass 8 to 13 WAP. Progressively increasing the $\mathrm{N}$ rate had little effect on turf color of either grass compared with applying $\mathrm{N}$ at $12 \mathrm{~kg} \cdot \mathrm{ha}^{-1} /$ week. The only significant turf color difference between the two programs occurred on zoysiagrass in the later weeks of 2008.

Although $\mathrm{N}$ was applied at $384 \mathrm{~kg} \cdot \mathrm{ha}^{-1}$ during the poly-coated urea (PCU) program, turf color of both grasses was not significantly higher than all other programs any WAP in any year. These results are likely the

Table 3. Mean squares from combined analyses of variance for turf color and turf coverage of 'Miniverde' bermudagrass and 'Diamond' zoysiagrass from the 2008 and 2009 establishment periods.

\begin{tabular}{lrcc}
\hline & \multicolumn{3}{c}{ Mean square } \\
\cline { 3 - 4 } Source of variation & Df & Color & Coverage \\
\hline \multirow{3}{*}{ Bermudagrass } & 4 & $44.3^{* *}$ & $3556.4^{* *}$ \\
Program (P) & 1 & $15.6^{* *}$ & $196.0^{*}$ \\
Year (Y) & 9 & $79.2^{* *}$ & $28660.7^{* *}$ \\
WAP (W) & 3 & 0.5 & $333.2^{* *}$ \\
Repetition (R) & 4 & $4.8^{* *}$ & $289.6^{* *}$ \\
P $\times$ Y & 36 & $0.5^{* *}$ & $176.3^{* *}$ \\
P $\times$ W & 9 & $8.7^{* *}$ & $1925.9^{* *}$ \\
W (Y) & 333 & 88.1 & 42.6 \\
Error & & 7.8 & 8.9 \\
CV \% & & 6.6 & 73.3 \\
Mean & & &
\end{tabular}

\begin{tabular}{lrrc}
\multicolumn{4}{c}{ Zoysiagrass } \\
Program (P) & 4 & $24.8^{* *}$ & $4923.2^{* *}$ \\
Year (Y) & 1 & $162.7^{* *}$ & $43143.0^{* *}$ \\
WAP (W) & 8 & $83.2^{* *}$ & $18390.7^{* *}$ \\
Repetition (R) & 3 & $0.4^{*}$ & 35.4 \\
$\mathrm{P} \times \mathrm{Y}$ & 4 & $5.8^{* *}$ & $543.3^{* *}$ \\
$\mathrm{P} \times \mathrm{W}$ & 32 & $0.3^{* *}$ & 38.6 \\
$\mathrm{~W}(\mathrm{Y})$ & 8 & $22.1^{* *}$ & $1328.6^{* *}$ \\
Error & 299 & 0.1 & 37.5 \\
$\mathrm{CV} \%$ & 5.6 & 11.6 \\
Mean & \multicolumn{4}{c}{6.6} & 52.9 \\
\hline$* * *$ Significance at 0.05 and 0.01 level, respectively. \\
zP = fertilization programs; Y = year (2008 and \\
2009); WAP = weeks after planting.
\end{tabular}

result of the slow release of $\mathrm{N}$ by the polymercoated urea prills. Stiglbauer et al. (2009) evaluated three quick-release $\mathrm{N}$ sources and found no difference in 'Diamond' zoysiagrass color during establishment when the same $\mathrm{N}$ rate was applied. PCU was the only slowrelease $\mathrm{N}$ source used in our study as a standalone program. Therefore, further research is needed to determine the influence of various slow-release N sources on 'Miniverde' bermudagrass and 'Diamond' zoysiagrass color during establishment.

Turfgrass coverage. Visual evaluation and digital image analysis were used to determine percent coverage during the establishment period. Bermudagrass correlation coefficients between visual coverage ratings and percent coverage calculated by digital image analysis were $0.90(P \leq 0.0001)$ in 2008 and $0.82(P \leq$ $0.0001)$ in 2009 . Zoysiagrass correlation coefficients were $0.86(P \leq 0.0001)$ and 0.87 $(P \leq 0.0001)$ in 2008 and 2009, respectively. Only the visual data are presented because percent coverage calculated by the image analyses was affected by algae growth that occurred during the first 6 weeks after planting in both years.

The combination program, $\mathrm{SU}-1.2+\mathrm{O}$, established turf the quickest over both years (Fig. 3). Bermudagrass and zoysiagrass under this program were $75 \%$ established 2 weeks earlier than other programs. However, there was more total $\mathrm{P}$ applied during $\mathrm{SU}-1.2+\mathrm{O}$ than with any other program. Rodriguez et al. (2001) found that fertilizers containing $\mathrm{P}$ maximized the establishment of three ultradwarfs, even on soils with a high $\mathrm{P}$ content. Total $\mathrm{N}$ applied during the $\mathrm{SU}-1.2+\mathrm{O}$ program was only $48 \mathrm{~kg} \cdot \mathrm{ha}^{-1}$ more than during $\mathrm{SU}-2.4$. Thus, the additional $\mathrm{P}$ in $\mathrm{SU}-1.2+\mathrm{O}$ might have attributed to increased establishment. Further research is needed to determine optimum $\mathrm{P}$ rates for the establishment of 'Miniverde' bermudagrass and 'Diamond' zoysiagrass.

With the exception of $\mathrm{SU}-1.2+\mathrm{O}$, increasing the $\mathrm{N}$ rate had little to no effect on the establishment of both grasses in both years. The establishment of turf under PCU was no different from under any other program despite receiving the most total $\mathrm{N}$. This response was similar to the turf color results and this is likely the result of the slow-release properties of the fertilizer. Increasing the $\mathrm{N}$ rate from 12 to $24 \mathrm{~kg} \cdot \mathrm{ha}^{-1} /$ week did not reduce time to $75 \%$ establishment for either grass, although the average coverage rate was greater for bermudagrass in both years and zoysiagrass in 2008 (Table 4). Previous zoysiagrass establishment studies have found that higher $\mathrm{N}$ rates do not always benefit coverage rates (Richardson and Boyd, 2001; Stiglbauer et al., 2009).

Stiglbauer et al. (2009) did find establishment differences in 'Diamond' zoysiagrass when sprigging rate was increased from 91 to $182 \mathrm{~m}^{3} \cdot \mathrm{ha}^{-1}$. The higher sprigging rate provided two times the turf coverage as the lower sprigging rate at 3 weeks after sprigging. With the higher sprigging rate, they were able to achieve $100 \%$ zoysiagrass establishment in $77 \mathrm{~d}$. The establishment rate results using the high sprigging rate is comparable with ours. However, our sprigging rate was $49 \mathrm{~m}^{3} \cdot \mathrm{ha}^{-1}$ less and total $\mathrm{P}$ applied was $31 \mathrm{~kg} \cdot \mathrm{ha}^{-1}$ more $(\mathrm{SU}-1.2+$ O program). These data suggest that a rapid establishment may be achieved through the applied fertility program and not require the additional planting material. The addition of $\mathrm{P}$ during 'Diamond' zoysiagrass establishment may have contributed to more rapid establishment with the reduced sprigging rate.

Guertal and Evans (2006) reported that ultradwarf bermudagrass required 34 to $43 \mathrm{~kg} \cdot \mathrm{ha}^{-1}$ per week to produce the most rapid establishment. Their study used constant $\mathrm{N}$ rate applications over the course of the study. The treatments $\mathrm{SU}-$ Prog. and $\mathrm{SU}-12+\mathrm{O}$ in this study used variable rates over the establishment weeks making it difficult to compare across all our treatments to previously reported data. In addition, the bermudagrass establishment result differences in this study compared with previous reports are possibly the result of the $\mathrm{N}$ source used. Guertal and Evans (2006) used soluble $\mathrm{N}$ sources without urease or nitrification inhibitors. Although the stabilized urea used in our programs was soluble, its inhibiting properties possibly disguised $\mathrm{N}$ rate differences between SU treatments. No research was found that used stabilized $\mathrm{N}$ for establishing turfgrasses, although Waddington et al. (1989) previously reported that stabilized $\mathrm{N}$ had no appreciable effect on turfgrass growth or color.

Bermudagrass and zoysiagrass coverage rate was calculated during the establishment period of each year (Table 4). Bermudagrass rates ranged from $1.13 \%$ to $1.44 \%$ per day in 2008 and 1.02 to $1.49 \%$ per day in 2009 . Zoysiagrass rates ranged from $0.86 \%$ to $1.3 \%$ per day in 2008 and 0.51 to $0.79 \%$ per day in 2009 . It was not fully understood why the zoysiagrass established so much slower in 2009 than 2008. One possible explanation may be the result of temperature variation between years.

The average maximum temperatures during the week before 2, 3, 5, and 6 WAP were higher in 2008 than 2009. Unruh et al. (1996) found that decreasing the temperature from 30 to $25^{\circ} \mathrm{C}$ decreased the growth rate of 'Meyer' zoysiagrass $\approx 3 \mathrm{~mm} \cdot \mathrm{d}^{-1}$. Thus, cooler air temperatures early in the 2009 growing season likely slowed the growth of the zoysiagrass in our study. The bermudagrass reached $100 \%$ coverage $\approx 2$ weeks earlier in 2009 than 2008, but at 5 WAP (Fig. 3), all bermudagrass treatments were $5 \%$ to $20 \%$ less established in 2009 than 2008. This response coincides with the lower temperatures for the first few weeks after planting. The zoysiagrass at 5 WAP was near 5\% established across all treatments in 2009 compared with nearly $40 \%$ in 2008 . The combination of reduced coverage rate at the start of the season and the overall slow growth of zoysiagrass in general lead to the much slower establishment in 2009.

Adding an organic fertilizer to a stabilized urea program had a significant effect on establishment, likely as a result of increased $\mathrm{N}$ and/or $\mathrm{P}$ applied. Grasses fertilized with the $\mathrm{SU}-1.2+\mathrm{O}$ had the highest growth rate across both years. There were little to no coverage rate differences among the three 


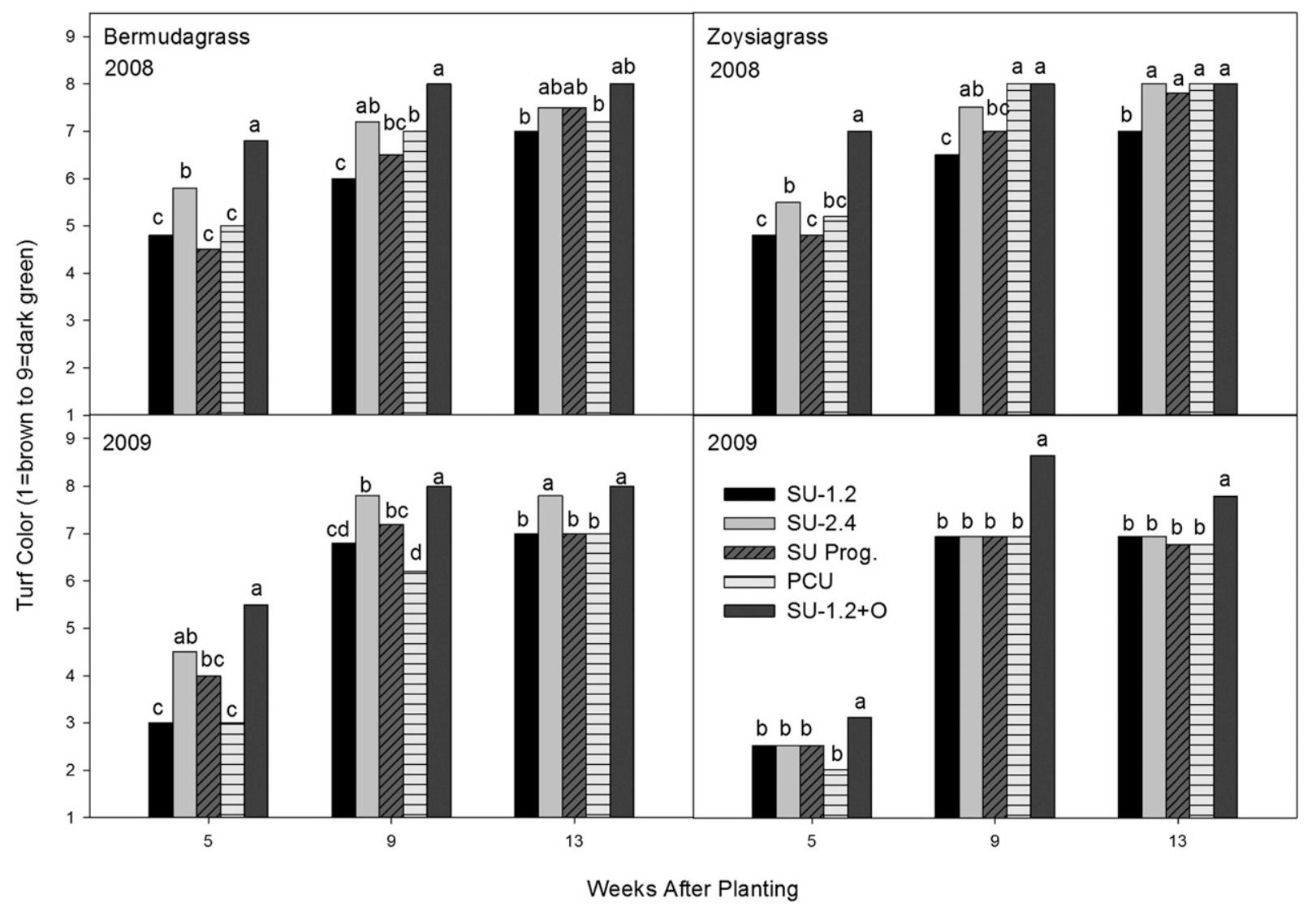

Fig. 2. Turf color of 'Miniverde' bermudagrass and 'Diamond' zoysiagrass during the 2008 and 2009 establishment periods. Mean separation between years and weeks after planting for each grass. Values with the same letter are not statistically different according to Fisher's least significant difference test at $P \leq 0.05$.

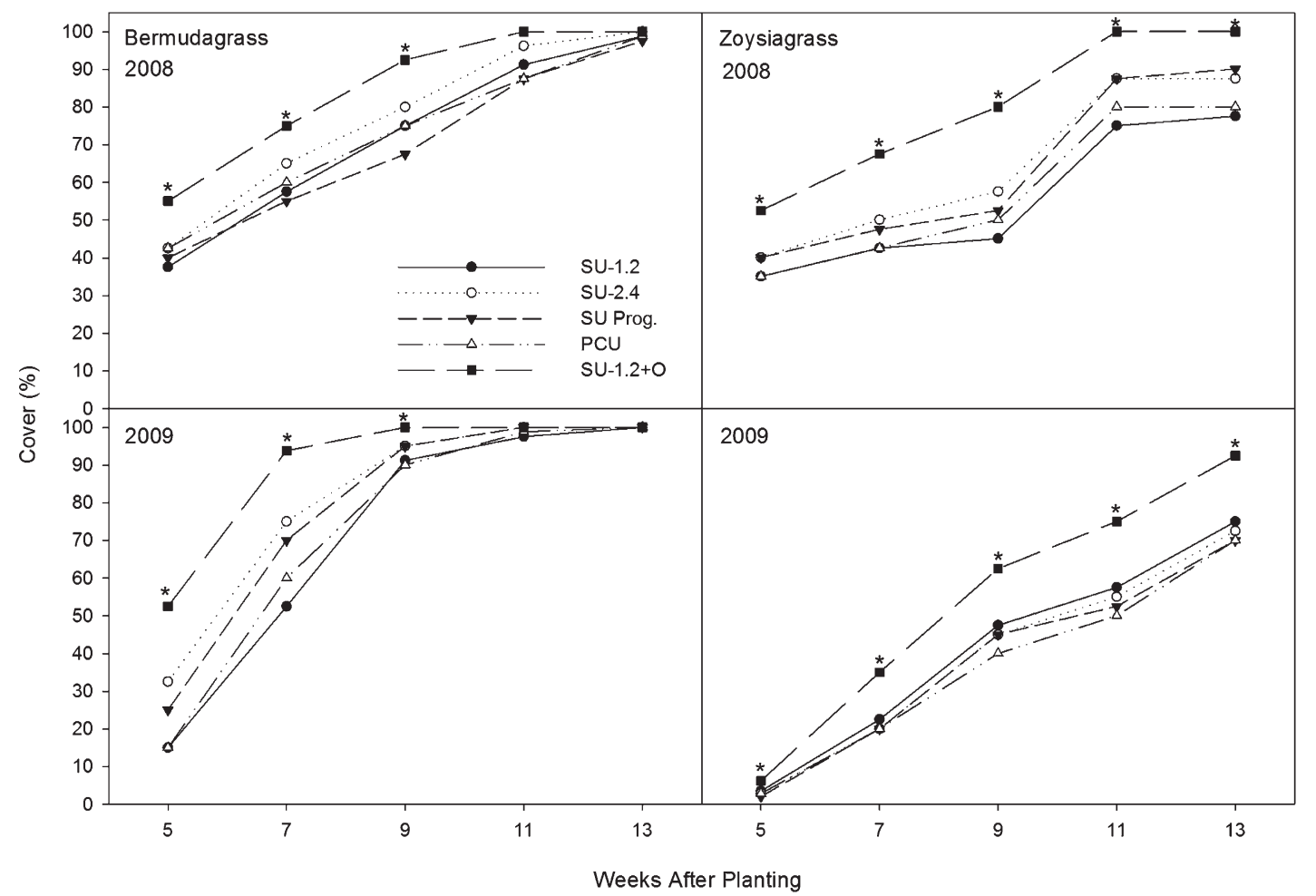

Fig. 3. Percent coverage of 'Miniverde' bermudagrass and 'Diamond' zoysiagrass during the 2008 and 2009 establishment periods. Mean separation between years and weeks after planting for each grass by Fisher's least significant difference test at $P \leq 0.05$. An asterisk indicates a significant difference from all other treatments at that specific date. 
Table 4. Coverage rate of 'Miniverde' bermudagrass and 'Diamond' zoysiagrass during the 2008 and 2009 establishment periods.

\begin{tabular}{|c|c|c|c|c|}
\hline \multirow[b]{3}{*}{ Program name } & \multicolumn{4}{|c|}{ Coverage $^{\mathrm{z}}$ (percent/day) } \\
\hline & \multicolumn{2}{|c|}{2008} & \multicolumn{2}{|c|}{2009} \\
\hline & Bermudagrass & $\overline{\text { Zoysiagrass }}$ & Bermudagrass & $\overline{\text { Zoysiagrass }}$ \\
\hline $\mathrm{SU}^{\mathrm{y}}-1.2$ & $1.18 \mathrm{~cd}$ & $0.86 \mathrm{c}$ & $1.02 \mathrm{c}$ & $0.59 \mathrm{~b}$ \\
\hline $\mathrm{SU}-2.4$ & $1.26 \mathrm{~b}$ & $1.03 \mathrm{~b}$ & $1.22 \mathrm{~b}$ & $0.55 \mathrm{~b}$ \\
\hline SU Progressive & $1.13 \mathrm{~d}$ & $1.00 \mathrm{~b}$ & $1.15 \mathrm{bc}$ & $0.55 \mathrm{~b}$ \\
\hline $\mathrm{PCU}^{\mathrm{x}}$ & $1.20 \mathrm{bc}$ & $0.91 \mathrm{c}$ & $1.04 \mathrm{c}$ & $0.51 \mathrm{~b}$ \\
\hline $\mathrm{SU}-1.2+\mathrm{O}^{\mathrm{w}}$ & $1.44 \mathrm{a}$ & $1.30 \mathrm{a}$ & $1.49 \mathrm{a}$ & $0.79 \mathrm{a}$ \\
\hline $\operatorname{LSD}(0.05)$ & 0.07 & 0.06 & 0.17 & 0.13 \\
\hline $\mathrm{CV} \%$ & 12.6 & 13.1 & 32.3 & 46.5 \\
\hline
\end{tabular}

${ }^{z}$ Values with the same letter within each column are not statistically different according to Fisher's LSD test at $P \leq 0.05$

${ }^{\mathrm{y}} \mathrm{SU}=$ stabilized urea.

${ }^{\mathrm{x}} \mathrm{PCU}=$ poly-coated urea.

${ }^{\mathrm{w}} \mathrm{O}=$ organic (activated sewage sludge).

LSD $=$ least significant difference.

stabilized urea programs across either year for both grasses. The results from these studies suggest that 'Miniverde' bermudagrass and 'Diamond' zoysiagrass establishment can vary considerably based on the $\mathrm{N}$ sources used in granular fertilizer programs.

\section{Conclusions}

'Miniverde' bermudagrass and 'Diamond' zoysiagrass can be established in the transition zone during the summer season (June to August) using granular fertilizer. 'Miniverde' achieved $100 \%$ coverage earlier than 'Diamond' during both years, $7 \mathrm{~d}$ in 2008 and $35 \mathrm{~d}$ in 2009. The large difference between years was the result of cooler temperatures during the early stages of growth in 2009. This slowed zoysiagrass growth to the point where coverage was $10 \%$ or less on the first rating date.

The program $\mathrm{SU}-1.2+\mathrm{O}$ increased bermudagrass and zoysiagrass turf color above the acceptable level earlier in the establishment period. Although the PCU program had the most total $\mathrm{N}$ applied, it did not enhance turf color significantly compared with the other programs. Progressively increasing the $\mathrm{N}$ rate every month had little to no effect on turf color. However, the color of the bermudagrass and zoysiagrass under SU -2.4 reached an acceptable level in less time than the color of the grasses under SU - 1.2.

Increasing the $\mathrm{N}$ rate from 12 to 24 $\mathrm{kg} \cdot \mathrm{ha}^{-1} /$ week in the stabilized urea programs had little to no effect on the establishment of either grass. This is consistent with the zoysiagrass literature but in contrast to bermudagrass literature. It is possible that the stabilized urea used in the programs provided $\mathrm{N}$ over a period of time overshadowing any $\mathrm{N}$ rate differences. The combination program, SU $1.2+\mathrm{O}$, increased bermudagrass and zoysiagrass establishment during both years. Our results suggest a 'Diamond' zoysiagrass sprigging rate of $133 \mathrm{~m}^{3} \cdot \mathrm{ha}^{-1}$ can be used when total $\mathrm{P}$ applied is at least $60 \mathrm{~kg} \cdot \mathrm{ha}^{-1}$.

It is essential to develop an adequate fertilizer program when establishing putting greens. Nutrient sources and rates need to be optimized for each situation so nutrition will not compromise plant health during establishment. Fertilizer programs that include a combination of stabilized urea and activated sewage sludge appear to enhance color and establishment of 'Miniverde' bermudagrass and 'Diamond' zoysiagrass more than programs with stabilized urea only. However, further research should investigate other programs that incorporate a combination of $\mathrm{N}$ source and different $\mathrm{N}$ and $\mathrm{P}$ rates. Making this information available would benefit turfgrass managers undergoing a grow-in with either one of these grasses.

\section{Literature Cited}

Bunnell, B.T., L.B. McCarty, and W.C. Bridges, Jr. 2005. 'TifEagle' bermudagrass response to growth factors and mowing height when grown at various hours of sunlight. Crop Sci. 45:575-581.

Busey, P. and B.J. Myers. 1979. Growth rates of turfgrasses propagated vegetatively. Agron. J. 71:817-821

Carroll, M.J., P.H. Dernoeden, and J.M. Krouse. 1997. Cultural methods to enhance zoysiagrass establishment: Herbicides give zoysiagrass sprigs the edge. Golf Course Mgt. 65:53-57.

Dudeck, A.E., C.H. Peacock, and T.E. Freeman. 1985. Response of selected bermudagrasses to nitrogen fertilization, p. 495-504. In: Lemaire, F. (ed.). Proc. 5th International Turfgrass Research Conference, Avignon, France, 1-5 July.
Engelke, M.C., P.F. Colbaugh, J.A. Reinert, K.B. Marcum, R.H. White, B. Ruemmele, and S.J. Anderson. 2002. Registration of 'Diamond' zoysiagrass. Crop Sci. 42:304-305.

Guertal, E.A. and D.L. Evans. 2006. Nitrogen rate and mowing height effects on TifEagle bermudagrass establishment. Crop Sci. 46:1772-1778.

Guertal, E.A. and R. White. 1998. Dwarf bermudagrasses demand unique care: Dense, short turf requires a constant battle with thatch. Golf Course Mgt. 7:58-60

Karcher, D.E. and M.D. Richardson. 2005. Batch analysis of digital images to evaluate turfgrass characteristics. Crop Sci. 45:1536-1539.

McCarty, L.B. and A. Canegallo. 2005. Tips for managing ultradwarf bermudagrass greens. Golf Course Mgt. 73:90-95.

McCarty, L.B. and G.L. Miller. 2002. Managing bermudagrass turf: Selection, construction, cultural practices and pest management strategies. Sleeping Bear Press, Chelsea, MI.

Morris, K.N. and R.C. Shearman. 2008. NTEP turfgrass evaluation guidelines. Natl. Turfgrass Evaluation Prog., Beltsville, MD. 4 Apr. 2011. $<\mathrm{http} / / /$ www.ntep.org/ reports/ratings.htm>.

Patton, A.J., G.A. Hardebeck, D.W. Williams, and Z.J. Reicher. 2004. Establishment of bermudagrass and zoysiagrass by seed. Crop Sci. 44: 2160-2167.

Richardson, M.D. and J.W. Boyd. 2001. Establishing Zoysia japonica from sprigs: Effects of topdressing and nitrogen fertility. HortScience 36:377-379.

Rodriguez, I.R., G.L. Miller, and L.B. McCarty. 2001. Bermudagrass establishment on high sand-content soils using various N-P-K ratios. HortScience 37:208-209.

Stiglbauer, J.B., H. Liu, L.B. McCarty, D.M. Park, J.E Toler, and K. Kirk. 2009. 'Diamond' zoysiagrass putting green establishment affected by sprigging rates, nitrogen sources, and rates in the southern transition zone. HortScience 44:1757-1761.

Trenholm, L.E., A.E. Dudeck, J.B. Sartain, and J.L. Cisar. 1997. Cynodon responses to nitrogen, potassium, and day-length during vegetative establishment. Intl. Turfgrass Soc. Res. J. 8:541-552.

U.S. Golf Association Green Section Staff. 1993. USGA recommendations for a method of putting green construction. The 1993 revision. USGA Green Section Record. 31:1-3.

Unruh, J.B., R.E. Gaussoin, and S.C. West. 1996. Basal growth temperatures and growth rate constants of warm-season turfgrass species. Crop Sci. 36:997-999.

USDA-NRCS Soil Survey Division. 2008. Official series description. 4 Apr. 2011. <http://www2. ftw.nrcs.usda.gov/osd/dat/C/CANDOR.html>.

Waddington, D.V., P.J. Landschoot, and N.W. Hummel, Jr. 1989. Response of Kentucky bluegrass turf to fertilizers containing dicyandiamide. Commun. Soil Sci. Plant Anal. 20:2149-2170.

White, R. 1999. Unleash the full potential of new bermudagrass cultivars. USGA Green Section Record. 37:16-18. 